\title{
Incorporation of viruses into the budget of microbial C-transfer. A first approach
}

\author{
G. Bratbak ${ }^{1}$, M. Heldal ${ }^{1}$, T. F. Thingstad ${ }^{1 * *}$, B. Riemann ${ }^{2}$, O. H. Haslund ${ }^{2}$ \\ ${ }^{1}$ Dept of Microbiology and Plant Physiology, University of Bergen, Jahnebk. 5, N-5007 Bergen, Norway \\ ${ }^{2}$ The International Agency for ${ }^{14} \mathrm{C}$-Determination, Water Quality Institute, Agern Allé 11, DK-2970 Hørsholm, Denmark
}

\begin{abstract}
Viral lysis of bacteria has been suggested to be a quantitatively important process in the removal of bacteria, and potentially also in the production of DOC, in the ocean. In order to investigate the quantitative role of viruses in the pelagic microbial ecosystem, a diel study was undertaken, comprising measurements of particulate and dissolved primary production, bacterial production, bacterial grazing by flagellates, bacterial lysis by viruses, and production of viruses. Estimates of algal

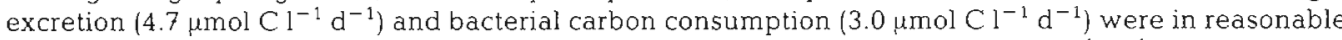

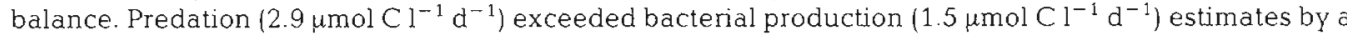
factor of 2. Major difficulties in balancing the budget emerged however, from the estimates of viral lysis

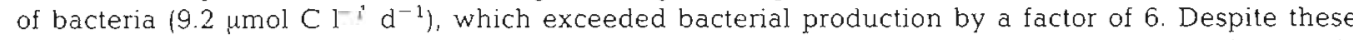
problems, results support the idea that viral lysis may be a quantitatively significant process that needs to be incorporated into budgets of microbial C-transfer.
\end{abstract}

\section{INTRODUCTION}

Several observations reported in the recent literature suggest directly or indirectly that viral lysis may be a process that influences the carbon flow through the pelagic microbial ecosystem in a quantitatively significant way. These observations include the high numbers of viruses (Bergh et al. 1989), combined with rapid fluctuations in these numbers in the productive season (Bratbak et al. 1990); the high frequency of cells containing recognizable viral particles (Proctor \& Fuhrman 1990 ), and the rapid decay of free viruses (Heldal \& Bratbak 1991). For bacteriophage production, the main alteration of the C-flow would be expected to be a diversion of part of the bacterial production from the predator pathway, recycling parts of the organic material back to the pool of dissolved organic carbon, either directly, or through the decay of the free viral particles (Fig. 1).

With the development of methods in aquatic microbiology that has taken place in recent years, it has become possible to estimate the carbon flow from primary production, through bacteria, to bacterial predators. By combining measurements of viral decay rate with numbers of viruses and with burst size estimates

\footnotetext{
- Author for correspondence
}

from electron microscopy observation of phage-producing bacteria, carbon flow in the 'viral loop' created by production of DOC from viral lysis of the bacteria can be incorporated into such budgets. The work presented here constitutes, to our knowledge, the first

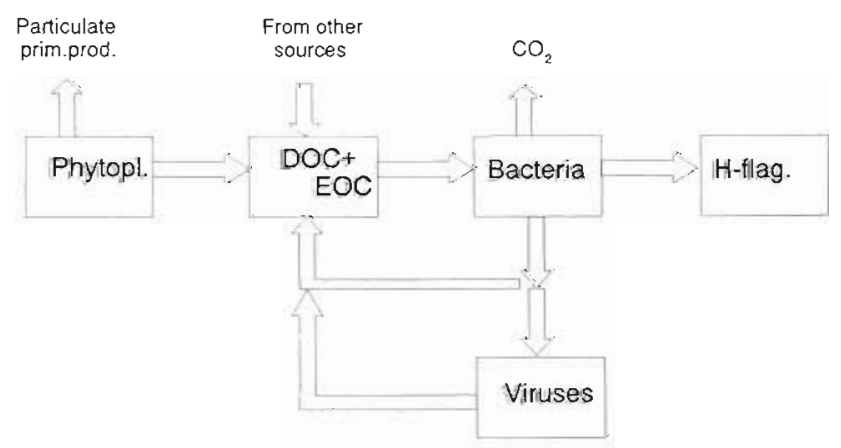

Fig. 1 Diagram of flows of organic material assumed to be associated with heterotrophic bacteria. The pool of dissolved organic carbon (DOC) is fed by excretion from phytoplankton (and other sources not indicated here); bacteria growing on this material are removed, either by predation from heterotrophic flagellates, or by viral lysis. Viral lysis releases the organic material of the bacterial cells, in part as new viral particles. Assuming that only a minor fraction of the viruses are successful in new infections, or adsorbing to larger particles, the virus production is also returned to the pool of DOC 
attempt to determine experimentally a complete budget of this kind.

Budgeting of element flows in the marine environment is inherently difficult due to the drifting of water masses in combination with potential imbalances in the food chain on short and long time scales. To overcome some of these difficulties, the system was studied through a diel cycle as part of a mesocosm experiment in Aarhus Bay, Denmark, in May 1991.

\section{METHODS}

General description of mesocosms. Enclosure experiments were carried out in Knebel Vig in May 1991. Knebel Vig is a small embayment of the east coast of Kalø Vig, which is part of the Bay of Århus. Knebel Vig has a maximum depth of $16 \mathrm{~m}$ and a surfdce ared of $37 \mathrm{~km}^{2}$ (see also Nybroe et al. 1992). The bag used in the experiment reported here was one of 6 transparent, cylindrical plastic enclosures $1.5 \mathrm{~m}$ in diameter and $4 \mathrm{~m}$ deep). These were filled with seawater on 10 May 1991 by pulling the top part of submerged enclosures towards the water surface. The enclosures were closed just above the sediment surface and fixed to a pontoon bridge. The water was kept in circulation by wind-driven mills. The diel experiment reported here was performed from 10:00 h on 22 May.

Water samples were taken at $2 \mathrm{~h}$ intervals. Samples from 3 depths $(10 \mathrm{~cm}$ below the surface, 1 , and $2.5 \mathrm{~m}$ ) were pooled before use in $5 \mathrm{l}$ plastic bottles. The samples were brought back to the laboratory within $30 \mathrm{~min}$ of sampling.

Viruses. Samples for counting and sizing of viruses $(100 \mathrm{ml})$ were preserved with $1 \%$ glutaraldehyde (final concentration). Virus and bacteria were harvested onto electron microscope grids by centrifugation and counted in the transmission electron microscope as previously described (Bratbak et al. 1990, Børsheim et al. 1990).

The viral decay, i.e. decrease in viral concentration over time, was recorded after inhibiting production of new viruses by adding KCN to a final concentration of 2 mmol $1^{-1}$ as described by Heldal \& Bratbak (1991). The $\mathrm{pH}$ of the $\mathrm{KCN}$ stock solution was adjusted to 8.5 . Samples $(100 \mathrm{ml})$ for counting of viruses were withdrawn at $1 \mathrm{~h}$ intervals and preserved with $1 \%$ glutaraldehyde. Viruses were counted as described above. The viral decay rate was calculated from the initial loglinear part of the decay curves using linear regression.

The frequency of bacteria containing mature phage particles and the number of phages released from the bacteria was determined after lysing the bacteria from without with streptomycin (Heldal \& Bratbak 1991). Water samples $(100 \mathrm{ml})$ were incubated with $0.3 \% \mathrm{w} / \mathrm{v}$ streptomycin (Sigma No. S-6501) for $1 \mathrm{~h}$ and then pre- served with $1 \%$ glutaraldehyde. Bacteria and viruses were harvested onto grids and counted in the electron microscope as described above.

Bacterial biomass and production. The number of bacteria was determined using the standard acridine orange direct count method (Hobbie et al. 1977). Cell volumes were estimated from measurements of cell dimensions from magnified black and white photographs (Fuhrman 1981, Lee \& Fuhmman 1987). Four pictures were taken from each filter, and a total of 100 cells were measured from each filter.

Bacterial net production was measured by means of ${ }^{3} \mathrm{H}$-thymidine incorporation (Fuhrman \& Azam 1980). Samples of $5 \mathrm{ml}$ were incubated in situ for 20 to $30 \mathrm{~min}$ using $12.5 \mathrm{nmol} \mathrm{l}^{-13} \mathrm{H}$-thymidine $\left(20 \mu \mathrm{Ci} \mathrm{nmol}^{-1}\right.$; Dupont, NEN Research Products, Boston, MA, USA). Blanks were prepared from samples with formalin added ( $1 \%$ in final solution) immediately before the addition of ${ }^{3} \mathrm{r}$-thymidine. After incubation, samples were filtered through $0.45 \mu \mathrm{m}$ pore-sized filters (Sartorius, cellulose nitrate, $25 \mathrm{~mm}$ diam.) and washed thoroughly with ice-cold TCA. Ten $\mathrm{ml}$ scintillation cocktail (Ultima Gold, Packard) was added, and the filters were counted after $24 \mathrm{~h}$ storage in a scintillation counter (Rack-Beta, LKB Instruments Inc., Rockville, MD, USA). To calculate cell production from incorporation of ${ }^{3} \mathrm{H}$-thymidine, a conversion factor of $1.1 \times 10^{18}$ cells $\mathrm{mol}^{-1}$ thymidine incorporated into TCA precipitate (Riemann et al. 1987) was used.

Phytoplankton primary production. A 11 bottle was incubated in situ $(0.5 \mathrm{~m}$ below the surface) with $40 \mu \mathrm{Ci}$ $\mathrm{NaH}^{14} \mathrm{CO}_{3}$ (The International Agency for ${ }^{14} \mathrm{C}$-Determination, Hørsholm, Denmark). At each sampling, $25 \mathrm{ml}$ subsamples were filtered through at $20 \mu \mathrm{m}$ mesh net, followed by a $2 \mu \mathrm{m}$ Nuclepore filter and a $0.45 \mu \mathrm{m}$ Sartorius membrane filter. A subsample of $10 \mathrm{ml}$ was assayed for total primary production by means of a modification of the acidification and bubbling procedure (Schindler et al. 1972, Riemann \& Jensen 1991). Instead of bubbling, the acidified samples were stored open for $24 \mathrm{~h}$ (Riemann \& Jensen 1991). The filters were treated with fuming $\mathrm{HCl}$ for $5 \mathrm{~min}$. Filters were dissolved in $10 \mathrm{ml}$ Filter Count (Packard), and counted in a scintillation counter (Rack-Beta, LKB Vallac). The standardization (i.e. radioactivity per $m$ l or ampoule) was compiled as described by Ursin \& Bresta (1980).

Phytoplankton carbon biomass. Duplicate samples were filtered onto $25 \mathrm{~mm}$ Whatman GF/C filters and extracted in $96 \%$ ethanol for 20 h without homogenization (Jespersen \& Christoffersen 1987). The pigment extracts were measured spectrophotometrically without correction for degradation products. A specific absorption coefficient of $83.4 \mathrm{~g}^{-1} \mathrm{l} \mathrm{cm}^{-1}$ for chlorophyll a was applied (Wintermans \& DeMots 1965). A phytoplankton carbon-to-chlorophyll ratio of 30 was applied. 
Flagellate grazing on bacteria. Grazing by heterotrophic flagellates on bacteria was measured by means of a fluorescence staining method (Sherr et al. 1987). Fluorescently labeled bacteria (FLB) were prepared from the population of natural bacteria at the experimental site concentrated by tangential flow equipment (Minitan, Millipore). The fraction between 0.1 and $0.8 \mu \mathrm{m}$ net pore size was stained with DTAF and frozen. In order to maintain the actual particle concentration, addition of the labeled bacteria was kept at 5 to $15 \%$ of the number of bacteria in the samples. Following incubation in situ for 15 to $20 \mathrm{~min}$, the samples were immediately fixed in $0.5 \%$ Lugol's solution and $3 \%$ formaldehyde, filtered onto $0.8 \mu \mathrm{m}$ black Nuclepore filters, and stored at $+2^{\circ} \mathrm{C}$. The food vacuoles of 40 to 75 heterotrophic flagellates were examined for content of FLB using an epifluorescence microscope. Grazing rates were based on ingestion of natural bacteria, picoalgae, and heterotrophic flagellates.

Flagellate carbon biomass. Autotrophic and heterotrophic flagellates were enumerated from proflavinestained preparations by epifluorescence microscopy (Haas 1982). Discrimination between autotrophic and heterotrophic flagellates was carried out by switching between blue and green excitation (for further details see Bjørnsen et al. 1988). Cell volumes were measured in the microscope from a subset of 3200 cells distributed over the entire data set. Biovolumes were converted to carbon biomasses by multiplying by $0.12{\mathrm{pgC} \mu \mathrm{m}^{-3}}^{-3}$

\section{RESULTS}

The most marked diel variation was observed in the primary production of particulate and dissolved material (Fig. 2A). Production of dissolved organic material was particularly pronounced in the evening. Summed primary production was in the range 0.5 to 1.4

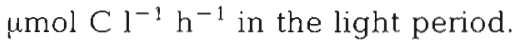

Bacterial production estimates from thymidine incorporation (Fig. 2B) also fluctuated with a maximum value at midday of $0.15 \mu \mathrm{mol} \mathrm{C} \mathrm{l}^{-1} \mathrm{~h}^{-1}$ (about $15 \%$ of the summed primary production), and a minimum du-

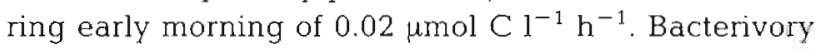

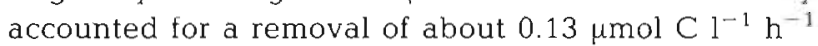
during the night and morning, possibly with slightly lower values in the afternoon (Fig. 2C). The maximum in bacterial production estimates from thymidine was thus comparable in magnitude to the estimated level of bacterivory. For the whole diel cycle, estimated preda-

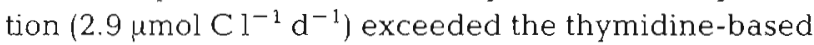

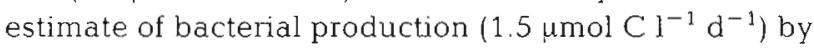
a factor of 1.9. Using the measured flagellate volumes (13 to $22 \mu \mathrm{m}^{3}$ ) and multiplying by a theoretical clear-
Fig. 2. Diel variations in (A) primary production; (B) bacterial production; (C) bacterivory; (D) bacterial numbers

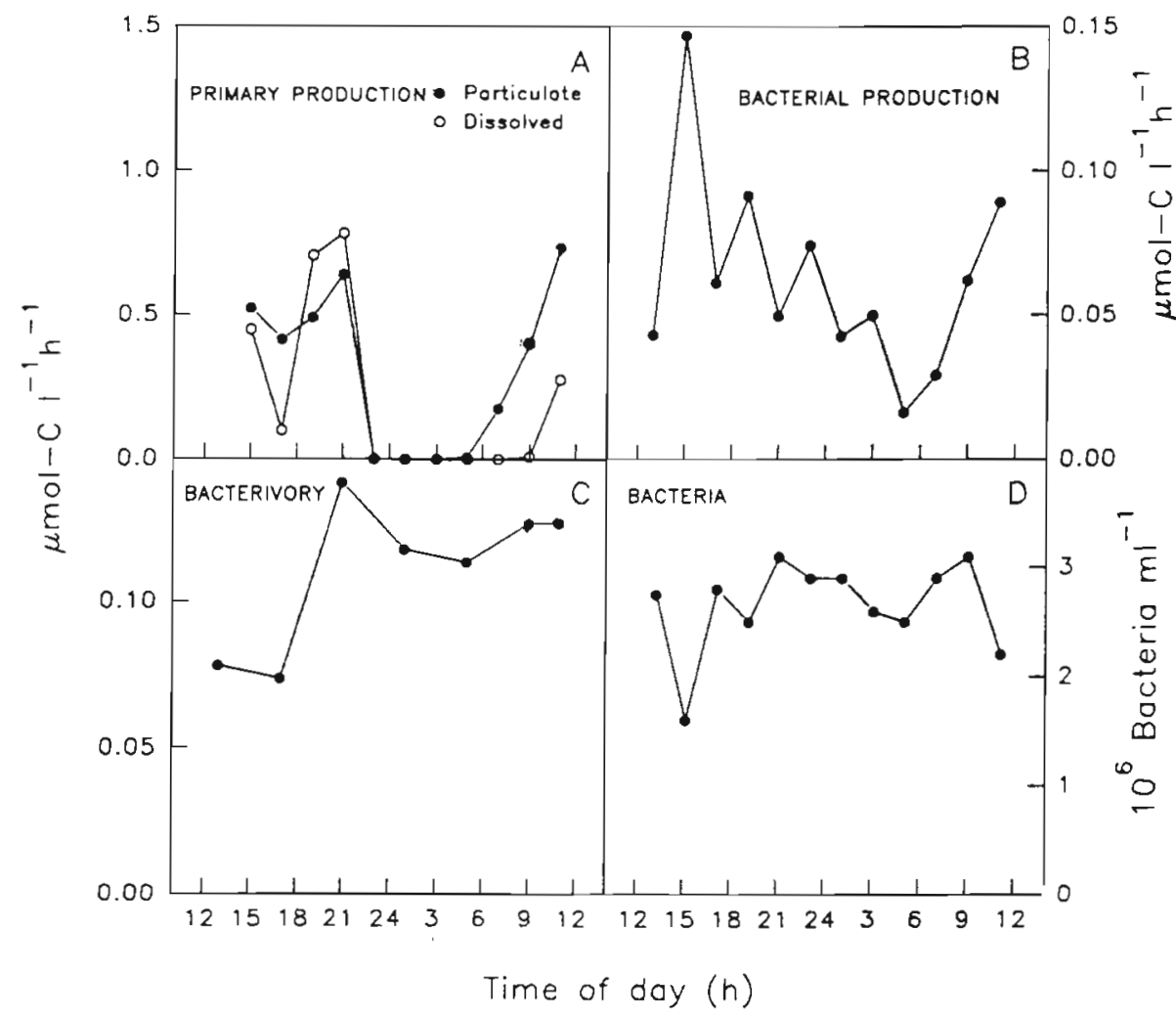


ance capacity of $10^{5}$ body volumes $\mathrm{h}^{-1}$ (Fenchel 1982),

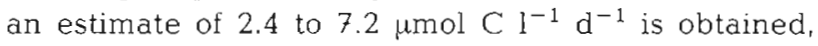
lending support to the experimentally obtained magnitude of bacterivory.

Between 12 and $29 \%$ of the bacteria were found to be in a virus-producing state with a diel variation characterized by high values in the afternoon and a minimum around midnight (Fig. $3 \mathrm{~A}$ ). The number of

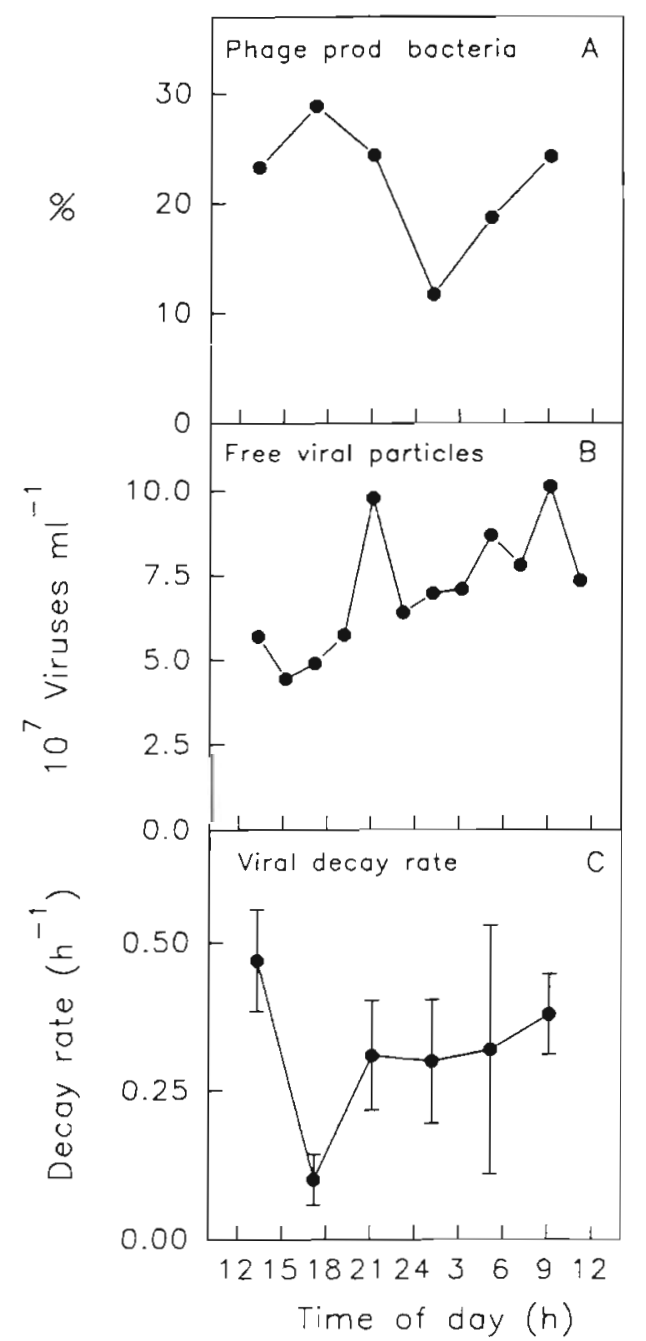

Fig. 3. Diel variations in (A) phage-producing bacteria; (B) free viral particles; (C) viral decay rates. Error bars indicate standard errors of decay rate estimates based on linear regressions on the type of data shown in Fig. 4

free viral particles started around $5 \times 10^{7} \mathrm{ml}^{-1}$, and showed a slightly increasing trend through the experiment. Decay rates of viruses (Fig. 3C) were, except for one high and one low measurement in the afternoon, found to be in the range 0.3 to $0.4 \mathrm{~h}^{-1}$ for $30 \%$ of the virus population, the rest decaying more slowly (Fig. 4).

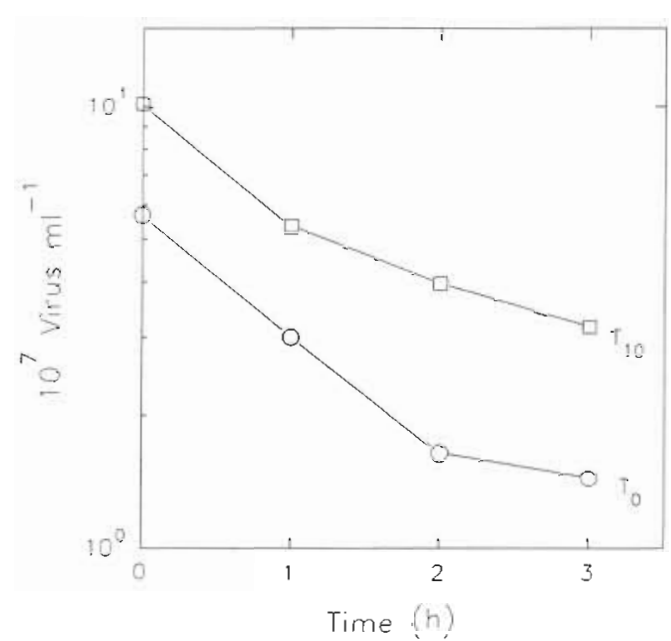

Fig. 4. Decay of viruses in samples treated with $\mathrm{KCN}$. Semilogarithmic plot

\section{Computation of carbon flow in the 'viral loop'}

To obtain a low estimate of carbon flow due to lysis of bacteria, only the rapidly decaying $1 / 3$ of the viral population is included in the rate calculations. With a mean total population of $7.1 \times 10^{7}$ viruses $\mathrm{ml}^{-1}$, and a decay rate of $0.3 \mathrm{~h}^{-1}$, a phage production of about $0.7 \times 10^{7}$ $\mathrm{ml}^{-1} \mathrm{~h}^{-1}$ is required to maintain equilibrium. Inspection of virus-producing bacteria (examples are shown in Fig. 5), led to a high estimate of the burst size: 100 phages produced per lysed bacterium. This implies a low estimate of bacterial loss of about $0.7 \times 10^{5} \mathrm{ml}^{-1}$ $\mathrm{h}^{-1}$ or $1.7 \times 10^{6} \mathrm{ml}^{-1} \mathrm{~d}^{-1}$. With a mean of $2.4 \times 10^{6}$ bacteria $\mathrm{ml}^{-1}$ estimated from fluorescence microscopy, this corresponds to a removal of $72 \%$ of the bacterial population by viral lysis $d^{-1}$. From epifluorescence microscopy, bacterial mean volume was estimated to $0.187 \mu^{3}$. With a conversion factor from volume to carbon of $350 \mathrm{fgC}^{-3}$ (Lee \& Fuhrman 1987) this corresponds to a carbon flow from lysed bacteria of 9.2

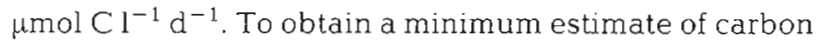
flux, the viral particles produced are assumed to be part

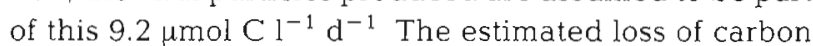
from the bacterial pool caused by viral lysis thus exceeds the thymidine-based bacterial production esti-

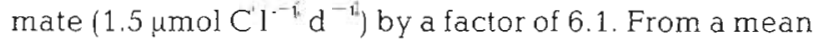
size of viral particles of $60 \mathrm{~mm}$, a density of 1.4 (Laskin \& Lechevalier 1973) and an assumed carbon content of $50 \%$, the production of viral particles amounts to 1.1

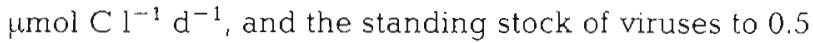
$\mu \mathrm{mol} \mathrm{Cl} l^{-1}$.

Assuming that only a minor fraction of the viruses produced eventually infects a new host, the major part of the material produced by bacterial lysis would be returned to the pool of organic material potentially 


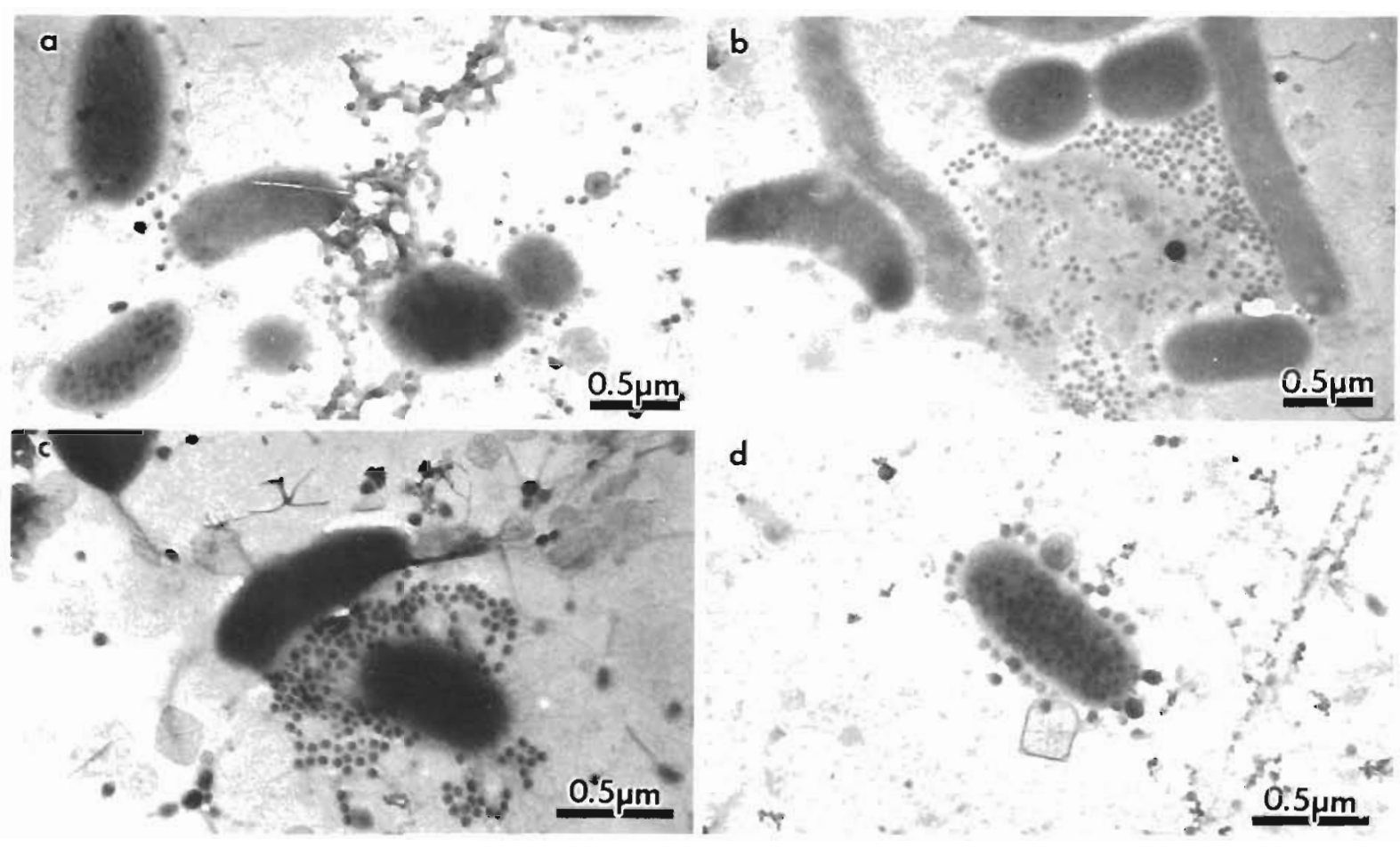

Fig. 5. Bacteria in various stages of lysis with mature phages in bacteria (a and d), and surrounding host bacteria (b and c)

available to bacterial consumption. Part of this material may be in the form of small particles, aggregates, or adsorbed to larger particles. In the flow scheme of Fig. 6, this aspect is neglected and all material $(9.2 \mu \mathrm{mol}$ $\mathrm{C}^{-1} \mathrm{~d}^{-1}$ ) is returned to the DOC pool.

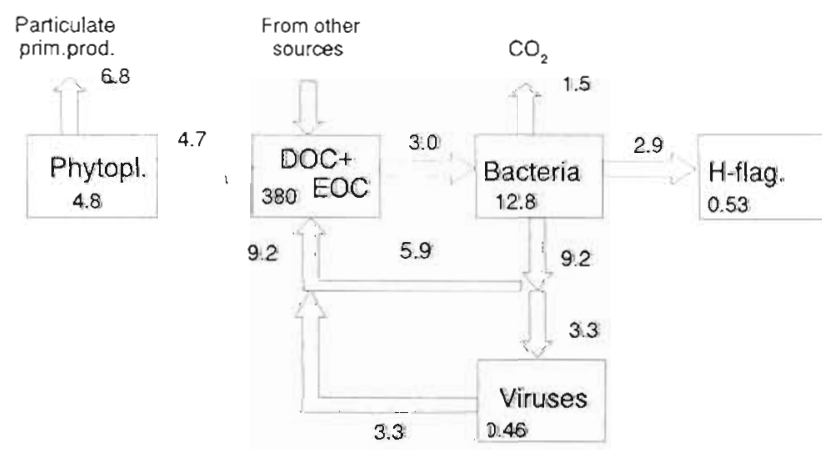

Fig. 6. Estimated diel carbon budget for the carbon flows associated with heterotrophic bacteria. Flows are in $\mu \mathrm{mol} \mathrm{Cl}^{-1}$ $\mathrm{d}^{-1}$, and biomasses in $\mu \mathrm{mol} \mathrm{Cl}^{-1}$

\section{DISCUSSION}

There is a discrepancy by a factor of nearly 8 between the production and the loss estimates for bacteria, with viral lysis as the dominating loss term. A corresponding net loss was not observed in the standing stock of bacteria through the diel cycle (Fig. 2D).
While the budget strongly suggests that viruses can be quantitatively important in the microbial cycling of matter, satisfactory conclusions cannot be drawn with the present imbalances in the calculated budget. Considering the short history of field application of the methods related to the viral loop, one would suspect that the cause for the imbalance is to be found in an overestimation of the lysis rate. The critical components in the estimation of this rate are (1) the viral decay rate, (2) the number of free viruses, and (3) the burst size.

Errors in conversion factors relating to estimation of the carbon content per bacterial cell will affect the thymidine production estimates and lysis rates proportionally, and not change their relative magnitude, unless one is willing to accept the possibility of a smaller carbon content per cell in virus-producing bacteria. Although the use of cyanide to stop virus production is a well-established technique in laboratory studies (Doermann 1952), the theoretical possibility remains that the unknown virus types in the marine environment may degrade faster under the influence of cyanide. Previous control experiments where the bacteria were removed by centrifugation did, however, result in decay rates not significantly different from those obtained with cyanide (Heldal \& Bratbak 1991). The number of viruses is at present based on the visual recognition of 'virus'-like particles in transmission electron micrographs. This implies an element of subjectiv- 
ity, which will have particularly serious consequences if the classification as viruses of the rapidly decaying subpopulation of particles should be wrong. With the techniques presently available, this element of subjectivity seems to be unavoidable. For the burst size, numbers were estimated from transmission electron micrographs showing recognizable virus particles inside or closely associated with bacteria. With the potential error arising if some of the viruses were covered, not developed to a stage where they could be recognized, or had escaped from the bacterial cell, we have used what we consider a high estimate of 100 viruses produced per bacterial cell lysed. A high estimate of burst size corresponds to a low estimate of the number of bacteria lysing. A factor of 6 wrong may seem difficult to accept for any single one of the factors involved. Errors of a factor 2 in each of the 3 involved numbers (decay rate, virus numbers, or burst size) cannot, however, be completely eliminated. Even if all of these hypothetical errors should affect the result in the same direction, the combined loss to predation and viral lysis would still exceed the bacterial production estimates.

Thymidine-based estimation of bacterial production is by now a well-established technique (Riemann \& Bell 1990), and large discrepancies in the budget are not expected to be caused by errors in this estimate. With the exception of some work aimed at establishing lysis rates (Servais et al. 1985), the concept of viral DNAproduction in the bacterial population has not, however, usually been incorporated into investigations applying the thymidine method. A theoretical possibility therefore remains that the experimental calibration curves for conversion of thymidine incorporation to cell production produce a conversion factor directly to net production of bacterial cells. This could occur because a production of bacterial cells balanced by viral lysis would not be reflected in increased bacterial cell numbers Some reports also indicate that DNA synthesis may be substantially higher than indicated by the incorporation of radioactive thymidine into DNA (Jeffrey \& Paul 1988, Bloem et al. 1989).

In a bag experiment, the possibility of wall effects will always be present. Our budget could therefore in theory be balanced by assuming that a large part of the viral loss rate in the water is balanced by production of viruses from bacteria attached to the walls of the bag If this was the case, one would expect a low frequency of virus-producing bacteria in the samples taken from the water column. In this experiment, however, up to $30 \%$ of the bacterial population was in a recognizable state of virus production. With our estimated burst size of 100 and a bacterial population of $2.4 \times 10^{6} \mathrm{ml}^{-1}$, the number of virus-producing bacteria in the water mass is sufficient to account for the required virus production of $0.7 \times 10^{7}$ viruses $\mathrm{ml}^{-1} \mathrm{~h}^{-1}$ if the duration of the phase in which internal viruses can be recognized lasts for $11 \mathrm{~h}$ or less. We have used a high estimate of burst size. If the estimate of burst size is halved, the maximum duration of the phase for which internal viruses are recognizable is halved to $5.6 \mathrm{~h}$.

Due to the assumed recycling to DOC of all material entering the viral loop, the budget discrepancies at the bacterial level also occur at the level of the DOC pool (Fig. 6). With removal of DOC from thymidine-based bacterial production and an assumed growth efficiency of $50 \%$, input to the DOC pool exceeds removal, even in the simplified flow diagram where DOC production by other sources in the food web are not included. If one roughly estimates that as much as $20 \%$ of the particulate primary production returns to the DOC pool from sources in the predator food chain such as egestion and sloppy feeding, this would give an additional

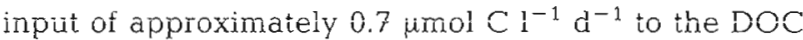
pool, still leaving the input from the viral loop as the dominant term. Compared directly to the estimates of primary production (Fig.6), the estimated flow of material in the viral loop is high: $87 \%$ of the sum of particulate and dissolved primary production.

From the budget considerations, the estimates of activity in the viral loop obtained by applying the techniques to a natural system may seem too high. While this application of these methods is new and experience is lacking, the estimates are to a large extent based on microscopic examination of fixed samples, i.e. samples not subject to the multitude of potential artifacts produced during incubation. One may therefore argue that the results are probably fairly robust. The only number relying on incubation is the viral decay rate. As one hypothetical confinement error, one could consider adsorption of viruses to the walls of the $11(5 \mathrm{~cm}$ radius) incubation bottles. Brownian displacement of viruses is, however, in the order of 0.12 to $0.4 \mathrm{~mm} \mathrm{~h}^{-1}$ (Bitton 1980). If, as a high estimate, all viruses in the outer $0.4 \mathrm{~mm}$ are assumed to adsorb to the wall in $1 \mathrm{~h}$, a disappearance rate from the aqueous phase of $0.02 \mathrm{~h}^{-1}$ can be estimated. Wall adsorption is thus not a likely cause for the rapid disappearance of viruses observed in the decay experiments. The stable virus population in bottles without $\mathrm{KCN}$ treatment observed by Heldal \& Bratbak (1991) also indicates that wall adsorption is not a major factor

To approach an understanding of the mechanisms governing bacterial viruses in natural waters, it is probably important to consider the difference between lytic and temperate phages. Proliferation of lytic viruses depends on the host cell concentration and these viruses may therefore play their most important role during blooms when the host cell concentration is relatively high. However, most phages found in natural 
aquatic environments are presumably temperate since more than $90 \%$ of all known bacteriophages are temperate (Freifelder 1987). The production of new viral particles in natural waters will thus depend on induction of virus production in lysogenic host cells. Lysogenic cells are immune against the virus they carry and mass mortality due to temperate viruses can therefore only be due to mass induction of virus production in a lysogenic population. A third possibility may be that temperate viruses by mutation may be a source of lytic forms (Lillehaug et al. 1991). The probability of a mutation arising is related to the number (not necessarily the concentration) of host cells involved, while the proliferation of this mutant is related to the concentration of host cells.

Our working hypothesis is that virus production in natural waters is due to induction in lysogenic bacteria. Virus production will thus not depend on infection and host cell concentration. Virus production is speciesspecific and mass mortality of one bacterial species may leave room for another species. Virus production may accordingly result in a shift in species composition without any observable change in total bacterial concentration. This is perhaps the major difference between viral control and grazing control of a bacterial community: viruses are species-specific and affect community composition while bacterivoric protozoa are particle-size-specific and affect the total concentration of bacteria.

As a general conclusion, no clear resolution of the budget discrepancies is as yet available. We have, on the other hand, not been able to identify obvious candidates for errors causing serious overestimation of carbon flux in the viral loop, and postulate that activity in the viral loop is of quantitative importance in the microbial food web.

Acknowledgements. This study was supported by the EEC MAST programme, contract no.0020, the Danish Natural Research Council, Danish Technical Research Council (J.-no. 11-8630 and 16-4806), and National Agency of Environmental Protection in Denmark (HAV90, Marine Research Programme in Denmark, contract no. 1.23) to B.R. and O.H.H. The Royal Norwegian Council for Scientific and Industrial Research (contract 27744) (T.F.T., G.B., and M.H.), The Norwegian Council for Fisheries Research (M.H.), the Norwegian Council for Science and the Humanities, project Marine Microbial Foods webs, through Prof. Ian Dundas (G.B.). The electron microscopy work was done at the Lab. for Electron Microscopy, University of Bergen. We thank Anne Næss and Torill Røeggen for technical assistance with the virus decay experiment.

\section{LITERATURE CITED}

Bergh, Ø., Børsheim, K. Y., Bratbak, G., Heldal, M. (1989). High abundance of viruses found in aquatic environments. Nature, Lond. 340: $467-468$
Bitton, G. (1980). Introduction to environmental virology. Wiley-Interscience, New York

Bjørnsen, P. K., Riemann, B., Horsted, S. J., Nielsen, T. G., PockSteen, J. (1988). Trophic interactions between heterotrophic nanoflagellates and bacterioplankton in manıpulated seawater enclosures. Limnol. Oceanogr 33: 409-420

Bloem, J., Ellenbroek, F. M., Bär-Gilıssen, M-J. B., Cappenberg, T E. (1989). Protozoan grazıng and bacterial production in stratified Lake Vechten estimated by fluorescently labeled bacteria and by thymidine incorporation. Appl. environ. Microbiol. 55: 1787-1795

Bratbak, G., Heldal, M., Norland, S., Thingstad, T F. (1990). Viruses as partners in spring bloom microbial trophodynamics. Appl. environ. Microbiol. 56: 100-1405

Borsheim, Y., Bratbak, G., Heldal, M. (1990). Enumeration and biomass estimation of planktonic bacteria and viruses by transmission electron microscopy. Appl. environ. Microbiol. 56: 352-366

Doermann, A. H. (1952). The intracellular growth of bacteriophages. J. gen. Physiol. 35: 645-656

Fenchel, T (1982). Ecology of heterotrophic micraflagellates. I. Bioenergetics and growth. Mar. Ecol. Prog. Ser. 8: 225-231

Freifelder, G. (1987). Microbial genetics. Jones and Bartlett Publishers, Inc., Boston

Fuhrman, J. A. (1981). Influences of method on the apparent size distribution of bacterioplankton cells; epifluorescence microscopy compared to scanning electron microscopy. Mar. Ecol. Prog. Ser 5: 103-106

Fuhrman, J. A., Azam, F. (1980). Bacterioplankton secondary production estimates for coastal waters of British Columbia, Antarctic, and California. Appl. environ. Microbiol. 39: 1085-1095

Haas, L. W (1982). Improved epifluorescence microscopy for observing planktonic microorganisms. Annls. Inst. Océanogr Paris 58: 261-266

Heldal, M., Bratbak, G. (1991). Production and decay of viruses in aquatic environments. Mar. Ecol. Prog. Ser. 72 : 205-212

Hobbie, J. E., Daley, J., Jasper, S. (1977). Use of Nucleopore filters for counting bacteria by fluorescence microscopy. Appl. environ. Microbiol. 33: 1225-1228

Jeffrey, W. H., Paul, J. H. (1988). Underestimation of DNA synthesis by $\left[{ }^{3} \mathrm{H}\right]$-thymidine incorporation in marine bacteria. Appl environ. Microbiol. 54: 3165-3168

Jespersen, A.-M., Christoffersen, K. (1987). Measurements of chlorophyll-a from phytoplankton using ethanol as extraction solvent. Arch. Hydrobiol. 109: 445-454

Laskin, A. I., Lechevalier, H. A. (1973). Handbook of microbiology. Vol I. Organismic microbiology. CRC Press, Cleveland

Lee, S., Fuhrman, J. A. (1987). Relationships between biovolume and biomass of naturally derived marine bacterioplankton. Appl. environ. Microbiol. 53: 1298-1303

Lillehaug, D., Lindquist, B. H., Birkeland, N. K. (1991). Characterization of $\varnothing \mathrm{LC} 3$, a Lactococcus lactis subsp. cremoris temperate bacteriophage with cohesive singlestranded DNA ends. Appl. environ. Microbiol. 57: 3206-3211

Nybroe, O., Christoffersen, K. Riemann, B. (1992). Survival of Bacillus licheniformis in seawater model ecosystems. Appl. environ. Microbiol. 58: 252-259

Proctor, L. M., Fuhrman, J. A. (1990). Viral mortality of marine bacteria and cyanobacteria. Nature, Lond. 343: 60-62

Riemann, B., Bell, R. (1990). Advances in estimating bacterial biomass and growth in aquatic systems. Arch. Hydrobiol. 118: 385-402 
Riemann, B., Bjornsen, P. K., Newell, S., Fallon, R. (1987) Calculation of cell production of coastal marine bacteria based on incorporation of ${ }^{3} \mathrm{H}$-thymidine. Limnol. Oceanogr 32: 471-475

Riemann, B., Jensen, L. M. (1991). Measurements of phytoplankton primary production by means of the acidification and bubbling method. J. Plankton Res. 13: 853-862

Schindler, D. W., Schmidt, R. V., Reid, R. A. (1972). Acidification and bubbling as an alternative to filtration in determining phytoplankton production by the ${ }^{14} \mathrm{C}$ method. $J$. Fish. Res. Bd Can. 29: 1627-1631

Servais, P., Billen, G., Rego, J. V (1985). Rate of bacterial

This article was presented by J. Gray, Oslo, Norway mortality in aquatic environments. Appl. environ. Microbiol. 49: 1448-1454

Sherr, B. F., Sherr, E. B., Fallon, R. D. (1987). Use of monodispersed, fluorescently labeled bacteria to estimate in situ protozoan bacterivory. Appl. environ. Microbiol. 53: 958-965

Ursin, C., Bresta, A M. (1980). On the application of the liquid scintillation counting of ${ }^{14} \mathrm{C}$-labelled phytoplankton. Comm. Meet. mt. Coun. Explor. Sea C.M.-ICES/L: 31

Wintermanns, J. F. G. M., De Mots, A. (1965). Spectrophotometric characteristics of chlorophylls $a$ and $b$ and their phaeophytins in ethanol. Biochim. Biophys. Acta 109: 448-453

Manuscript first received: February 15, 1992

Revised version accepted: April 28, 1992 